\title{
Biodiversity and antimicrobial activity of endophytes associated with Egyptian medicinal plants
}

\author{
Selim KA ${ }^{1}$, El-Beih AA ${ }^{1, *}$, AbdEl-Rahman TM$^{2}$ and El-Diwany $\mathbf{A I}^{1}$ \\ ${ }^{1}$ Chemistry of Natural and Microbial Product Department, National Research Center, 12622 Dokki, Cairo, Egypt. \\ ${ }^{2}$ Botany Department, Faculty of Science, Cairo University, Giza, Egypt.
}

Selim KA, El-Beih AA, AbdEl-Rahman TM, El-Diwany AI. 2011 - Biodiversity and antimicrobial activity of endophytes associated with Egyptian medicinal plants. Mycosphere 2(6), 669-678, Doi 10.5943/mycosphere/2/6/7

One-hundred and thirty-two endophytic strains were isolated from 18 medicinal plants from Saint Katherine Protectorate, Egypt. Some of the endophytes were identified to genus or species level using traditional morphological methods, but most were classified as sterile mycelia. The relative frequency, isolation rate, and colonization rates of endophytes were used to express the diversity of endophytes. Most endophyte isolates were obtained from Euphorbia sanctae-catharinae (15 isolates). Galium sinaicum yielded the greatest endophytic diversity with eight taxa while Thymus decussates yielded only one taxon. Mycelia sterilia and Acremonium species were the dominant fungal endophytes, and some of these endophytes exhibited host specificity. Fifty-five of 99 tested endophytes showed a broad spectrum of inhibitory activity against different pathogenic bacteria and yeasts.

Key words - Acromonium sp. - antibacterial activity - anticandidal activity - biodiversity endophytes - Mycelia sterilia - Saint Katherine - medicinal plants

\section{Article Information}

Received 11 November 2011

Accepted 1 December 2011

Published online 31 December 2011

*Corresponding author: Ahmed A. El-Beih - e-mail - elkas_sci@yahoo.com, aae2eg@yahoo.com

\section{Introduction}

Plants may serve as a reservoir of large numbers of microorganisms known as endophytes (Bacon \& White 2000). Endophytes are microorganisms (mostly fungi and bacteria) that inhabit plant hosts for all or part of their life cycle. They colonize the internal plant tissues beneath the epidermal cell layers without causing any apparent harm or symptomatic infection to their host, living within the intercellular spaces of the tissues and its seems that they may penetrate the living cells (Strobel 2003). Endophytic fungi are an ecological, polyphyletic group of highly diverse fungi, mostly belonging to ascomycetes and anamor-phic fungi (Huang et al. 2001, Arnold 2007).

Individual plants may be host to one or more endophytes, and many endophytes may colonize certain hosts, suggesting that there may be many undiscovered endophyte species (Petrini 1991, Strobel \& Daisy 2003, Huang et al. 2007). Most of endophytes produce a plethora of bioactive metabolites that may be involved in the host-endophyte relationship (Strobel 2003). These metabolites may serve as sources of novel natural products for exploitation in medicine, agriculture, and industry (Bacon \& White 2000, Strobel \& Daisy 2003). The described populations of endophytic strains are few, which means there are good opportunities to find new endophytes that colonize plants in different niches and ecosystems.

Endophytic fungi represent an important and quantified component of fungal biodiversity, and are known to affect on plant community diversity and structure (Sanders 2004, Gonthier et al. 2006, Krings et al. 2007). A variety of relationships can exist between endophytes and 
their host plants, ranging from mutualism or symbiosis to antagonism or slight pathogenesis (Schulz \& Boyle 2005, Arnold 2007).

Host-endophytes relationships can be described in terms of host-specificity, hostrecurrence, host-selectivity, or host preference (Zhou \& Hyde 2001, Cohen 2006). Hostspecificity is a relationship in which a microorganism is restricted to a single host or a group of related species, and such specificity implies that complex biochemical interactions are occurring between the host and its associated endophytes (Holliday 1998, Strobel 2003, Strobel \& Daisy 2003). Host-recurrence refers to the frequent or predominant occurrence of endophytes in a particular host or a range of plant hosts, although the endophytes may also be found infrequently in other host plants in the same habitat (Zhou \& Hyde 2001). A single endophytic species may form relationships with two or many related host plants, but where there is a preference for one particular host the phenomenon is defined as host selectivity (Cohen 2006). The term host-preference is most frequently used to indicate a common occurrence or uniqueness of occurrence of endophytes in a particular host, and is also used to indicate the difference in endophytic community composition and relation frequencies from different host plants (Suryanarayanan \& Kumaresan 2000). Endophytes are also able to colonize multiple host species of the same plant family within the same habitat, and the distribution of some endophytes can be similar in closely related plant species (Huang et al. 2008). The differences in endophytes in their metabolic profile, and hence in their biological activity, even if between isolates of a species, might be related to the chemical difference of host plants (Paulus et al. 2006); this raises the importance of studying host-endophytes relationships, and the effect of host plants on endophytic metabolite production. More attention is now being given to study endophytic biodiversity, the chemistry and bioactivity of endophytic metabolites, and the relation between endophytes and their host plants (Tan \& Zou 2001, Schulz et al. 2002).

The Sinai Peninsula, which is a part of the Sahara-Arabian deserts, covers approximately $6 \%$ of the total land area of Egypt and is characterized by an arid to extremely arid climate with Mediterranean influences, i.e., aridity, winter precipitation and moderate tem- perature (Danin 1978). The Saint Katherine Protectorate covers $4350 \mathrm{~km}^{2}$ of mountainous region (average 1500-2000 m above mean sea level) of Southern Sinai and is a protected area due to its immense biological and ecological interest. Saint Katherine Protectorate contains 472 plant species including 19 Egyptian endemic species, 115 of medicinal interest, and about 170 species used in folk medicine. Medicinal plants have been recognized as a repository of endophytes with novel metabolites of pharmaceutical and agriculture importance (Strobel et al. 2004). Due to the richness of medicinal plants in Saint Katherine Protectorate and its unique environmental characters, this area is receiving increased attention for biological and ecological studies, and is considered an interesting area for studying endophytic community (Strobel \& Daisy 2003). The biodiversity of microbial community in Sinai is poorly known and thus, we focus this study on determining the structure, host specificity, and diversity of endophytic mycobiota of some medicinal plants in Saint Katherine Protectorate, and to study the effect of host plants on activity and metabolic profile of endophytes. Antimicrobial activity was used as pointer to compare between endophytic activities of different strains in this study.

\section{Methods \\ Study area}

The Saint Katherine Protectorate has an extremely arid climate with long, hot and rainless summers and cool winters. The mean annual precipitation in Saint Katherine area over 25 years is $45 \mathrm{~mm}$ per year, although the high mountains receive more precipitation (100 $\mathrm{mm} /$ year) as rain and snow. In some parts of this area, floods resulting from continual rain may occur during winter and spring. The mean maximum air temperature ranged from $15.1^{\circ} \mathrm{C}$ to $32.7^{\circ} \mathrm{C}$ and the mean minimum temperature ranges from $1.9^{\circ} \mathrm{C}$ to $20.2^{\circ} \mathrm{C}$, with the lowest temperature in December and January and the highest temperature in July and August (Mosallam 2007).

\section{Collection of host plants}

Leaves and stems of 18 host medicinal plants from seven families (Adiantaceae, Asteraceae, Ephedraceae, Euphorbiaceae, Hypericaceae, Lamiaceae, and Rubiaceae) were collected from Saint Katherine Protectorate, in 
September 2010. The plants were selected according to their ethnobotanical uses in traditional medicines, and only apparently healthy and disease free plants were selected in order to minimize the presence of plant pathogenic and saprobic species, and to prevent the isolation of localized pathogenic endophytic microorganisms. The collected plant materials were stored in separate plastic bags at $4^{\circ} \mathrm{C}$ in an ice box until isolation could commence (Strobel \& Daisy 2003).

\section{Isolation and identification of endophytic fungi and storage}

Following Arnold et al. (2000) the plant material was washed in running tap water, leaves of each plant were cut into $2 \mathrm{~mm}^{2}$, and branches were cut randomly to small pieces (5 mm long). The pieces were surface sterilization by sequentially dipping into $0.5 \%$ sodium hypochlorite (2 $\mathrm{min}$ ) and $70 \%$ ethanol (2 min), then rinsed with sterile water and allowed to surface-dry under sterile conditions. Tissue pieces were placed on both PDA (potato-dextrose-agar) medium and Czapeks agar medium. Both media were supplemented with chloramphenicol $(50 \mathrm{mg} / \mathrm{L})$ to suppress bacterial growth, and incubated at $30^{\circ} \mathrm{C}$. They were checked every day for 3 weeks and individual fungal colonies were transferred to fresh PDA plates for purification and identification purposes. Taxonomic identifycation of the fungi was based on their morphological characters and the mechanism of spore production (Moubasher 1993). Isolates that failed to produce reproductive structures after 34 months of incubation were referred to as mycelia sterilia, and divided into morphospecies according to their culture characteristics; this group of fungi is prevalent in endophyte studies (Lacap et al. 2003). Stock fungal cultures were deposited at Chemistry of Natural and Microbial Product Department, National Research Center, Egypt.

Cultivation and extraction of the fermentation broth

Pure strains of endophytes were inoculated into $100 \mathrm{ml}$ PD (potato-dextrose) broth in Erlenmeyer flasks and incubated at $30^{\circ} \mathrm{C}$, statically. After 21 days of incubation, the fungal mats were separated out by filtration. Dried fungal biomass was extracted by soaking in ethyl acetate $(1: 50, w / v)$ overnight. Super- natant was then extracted twice with equal volume of ethyl acetate $(1: 1, \mathrm{v} / \mathrm{v})$, and the upper organic phase of supernatant were add to mycelia extract. The organic phase was concentrated to dryness under reduced pressure using a rotary evaporator below $55^{\circ} \mathrm{C}$ to obtain the crude fungal extract. In case of endophytic bacteria and yeasts the supernatant was centrifuged first at $3600 \mathrm{rev} / \mathrm{min}$ for $10 \mathrm{~min}$ before extraction with ethyl acetate.

\section{Screening the relations between endophytes and their host plants}

Colonization rate (CR) was calculated as the total number of plant tissue pieces colonized by endophytes divided by the total number of pieces incubated for that plant sample, and expressed as a percentage. Isolation rate (IR) is a measure of endophyte richness in a given sample of plant tissue, i.e., the incidence of multiple colonization of endophytes per piece, and was calculated as the number of isolates obtained divided by the total number of tissue pieces, but not expressed as a percentage. Relative frequency (RF) of isolation, used to represent fungal density, was calculated as the number of isolates of a species divided by the total number of isolates, and expressed also as a percentage (Photita et al. 2001; Huang et al. 2008).

\section{Biological evaluation of endophytes using disc diffusion assay for antibacterial, and anticandidal activity}

The antibacterial and anticandical activity of the endophytic extracts were tested against three Gram positive bacteria (Staphylococcus aureus ATCC 29213, Bacillus subtilis NRRL-B-4219, Micrococcus luteus B-287), four Gram negative bacteria (Escherichia coli ATCC 25922, Pseudomonas aeruginosa ATCC 27953, Klebsiella pneumoniae ATCC 10131, Alcaligenes faecalis B-170), and four yeasts (Candida albicans ATCC 10231, C. tropicalis ATCC 750, C. parapsilosis ATCC 22019, Saccharomyces cerevisiae ATCC 2180-1A). The assay was preformed according to Jorgensen \& Turnidge (2007) with some modification. Nutrient agar (NA) media was used for test bacteria, and PDA media was used for test yeasts. The test organisms were inoculated over the surface of the sterilized media, with $1.5 \times 10^{8} \mathrm{CFU} / \mathrm{mL}$ (colony-forming units) for bacteria and $4 \times 10^{7}$ $\mathrm{CFU} / \mathrm{mL}$ for yeasts. The crude extracts were 
dissolved in methanol, and sterile disks of Wattman No. $3(6.0 \mathrm{~mm}$ in diameter) were loaded with $250 \mu \mathrm{g}$ of different endophytic extracts, dried, and then each disk placed on agar surface of freshly inoculated medium with the test microorganisms. A control test for the solvent was also preformed. The Petri dishes were kept in a refrigerator for one hour to permit homogenous diffusion of the antimicrobial agent before growth of the test microorganisms, and the plates were then incubated at $37^{\circ} \mathrm{C}$ for 24 hours. The appearance of a clear inhibition zone around the disk in the inoculated Petri dishes is an indication of antimicrobial activity, and the diameters of the clear zones surrounding the discs were measured.

\section{Result and discussion}

\section{Biodiversity of endophytic fungi associated with Saint Katherine medicinal plants}

From 18 Saint Katherine medicinal plants 132 endophytic isolates were identified morphologically into 29 taxa (Table 1). Most isolates were obtained from Euphorbia sanctaecatharinae (15 isolates), followed by Ephedra alata and Galium sinaicum (12 isolates from each). Bacterial endophytes were obtained from only Ephedra alata and Thymus decussates, in the presence of antibiotic in the isolation media, this may reveal that these endophytic bacteria have special features in resistance to antibiotic. $E$. alata showed the presence of both endophytic bacteria and fungi, but only bacteria were obtained from T. decussates. Unusually, Hypericum sinaicum yielded an endophytic yeast.

Using traditional morphological techniques, only some fungal isolates could be identified to species level, and a few identified to genus level, but some could not be identified as they were sterile, a common problem associated with identification of fungal endophytes (Gamboa \& Bayman 2001, Promputtha et al. 2005 a). Sterile fungi are prevalent in endophyte studies (lacap et al. 2003). The mycelia sterilia were divided into two morphospecies "Dark sterile mycelia and White sterile mycelia" according to their culture characters.

Mycelia sterilia were dominant endophytes, $19.69 \%$ for dark sterile mycelia and $18.93 \%$ for white sterile mycelia and these percentages agree with many endophytic studies (Fröhlich et al. 2000, Promputtha et al. 2005b,
Huang et al. 2008). Acremonium species are frequently identified as endophytes (Wicklow et al. 2005, Wicklow \& Poling 2009, De Almeida et al. 2011) and this genus was the second most frequent fungus with relative frequency of 12.87 $\%$, followed by Aspergillus, Penicillium, Pleospora tarda, and Ulocladium spp., with relative frequencies of $10.6 \%, 9.09 \%, 4.5 \%$, and $4.5 \%$, respectively (Fig. 1).

\section{Host recurrence and host specificity of endophytes}

All 18 medicinal plants were found to be host to one or more endophytes. The colonization rate and the isolation rate of endophytes from these plants ranged from $33.3 \%$ to $100 \%$, and 0.05 to 0.75 , respectively. Different endophytic taxa showed different relative frequencies in different plants (Fig. 2). Among the 18 medicinal plants, Galium sinaicum had the highest endophytic diversity with eight taxa, followed by Euphorbia sanctae-catbarinae, Hypericum sinaicum, and Teucrium polium with six taxa. Teucrium leucocladum and Thymus decussatus had the lowest endophytic diversity, with only an endophytic bacterium for Thymus decussatus, and two taxa of endophytic fungi for Teucrium leucocladum. Most endophytic isolates (15) were obtained from leaves of Euphor-bia sanctaecatbarinae (6 taxa), Among these taxa, Acromonium strictum and white sterile mycelia were the most frequent with $26.66 \%$ relative frequency followed by dark sterile mycelia, Aspergillus sydowii, Penicillium coleurophylium, and Phoma leveilleia, with relative frequency of $20 \%, 13.33 \%, 6.66 \%$, and $6.66 \%$, respectively.

Endophytes with the wide distribution and highest isolate abundance were mycelia sterilia, found in most host plants, except Adiantum capillus-veneris, Launea spino-sa, Thymus decussates, and Galium sinaicum. Fourteen plants were colonized by sterile mycelia with high relative frequency (38.6\%) for all plants, and sterile mycelia had high relative occurrence in nine plants with relative frequency above $40 \%$, especially in Teucrium leucocladum with $100 \%$ relative frequency of sterile mycelia. Aspergillus and Pencillium were the second most abundant genera, found in 9 host plants, with major occurrence in $S$. aegyptiaca (relative frequency $42.8 \%$ for Aspergillus) and in Adiantum capillusveneris (relative frequency 
Table 1 Number of endophyte colonies isolated from 18 Saint Katherine medicinal plants

\begin{tabular}{|c|c|c|c|c|c|c|c|c|c|c|c|c|c|c|c|c|c|c|c|c|c|c|c|c|c|c|c|c|c|c|c|c|}
\hline $\begin{array}{l}\text { Plant host /Fungal } \\
\text { Isolates }\end{array}$ & $\begin{array}{l}\text { A } \\
\text { b }\end{array}$ & $\begin{array}{c}\text { Ac. } \\
\text { sp. }\end{array}$ & $\begin{array}{c}\text { Ac. } \\
\text { st }\end{array}$ & $\begin{array}{l}\text { A } \\
\mathbf{1}\end{array}$ & $\begin{array}{l}\text { As. } \\
\text { fla }\end{array}$ & $\begin{array}{l}\text { As. } \\
\text { nig }\end{array}$ & $\begin{array}{l}\text { As. } \\
\text { sp. }\end{array}$ & $\begin{array}{l}\text { As. } \\
\text { sy }\end{array}$ & $\mathbf{B}$ & $\begin{array}{c}\text { C } \\
\mathbf{h} \\
\text { gl } \\
\mathbf{0}\end{array}$ & $\begin{array}{c}\text { Chs } \\
\text { pr }\end{array}$ & Co & $\begin{array}{l}\mathbf{E} \\
\mathbf{m}\end{array}$ & Eu & $\begin{array}{l}\text { Fu. } \\
\text { ox }\end{array}$ & $\begin{array}{l}\text { Fu. } \\
\text { Sp. }\end{array}$ & $\begin{array}{c}\text { D. } \\
\text { M.S. }\end{array}$ & $\begin{array}{c}\text { W. } \\
\text { M. } \\
\text { S. }\end{array}$ & Mu & $\mathbf{N i}$ & $\begin{array}{l}\text { Pn. } \\
\text { ch }\end{array}$ & $\begin{array}{r}\text { Pn. } \\
\text { co }\end{array}$ & $\begin{array}{l}\text { Pn. } \\
\text { sp. }\end{array}$ & $\mathbf{P h}$ & $\mathbf{P l}$ & Sc & $\begin{array}{l}\text { Ul. } \\
\text { at }\end{array}$ & $\begin{array}{l}\text { U } \\
\text { l. } \\
\text { c } \\
\text { h }\end{array}$ & $\mathbf{Y}$ & $\begin{array}{c}\text { Tota } \\
\text { l } \\
\text { End } \\
\text { o- } \\
\text { phyt } \\
\text { e }\end{array}$ & $\begin{array}{l}\text { C.R. } \\
\text { (\%) }\end{array}$ & I.R. \\
\hline \multicolumn{33}{|l|}{ Adiantaceae } \\
\hline Adiantum capillus-veneris & & & & 1 & & & & & & 2 & & & & & & & & & & & & & 1 & & & & & & . & 4 & 33.3 & 0.44 \\
\hline \multicolumn{33}{|l|}{ Asteraceae } \\
\hline Achillea fragrantissima & & & 3 & & & & & & & & & & & & & & 2 & 2 & & & & 1 & 1 & & & & & & 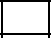 & 9 & 90 & 0.45 \\
\hline Artemisia herba alba & & & & & 2 & & & & & & & & & & & & 1 & 2 & & 2 & & & & & & & & & & 7 & 75 & 0.35 \\
\hline Chiliadenus montanus & & & 1 & & & & & & & & & & & & & & 1 & & & 1 & & & & & & & & & & 3 & 50 & .15 \\
\hline Launea spinosa & & 1 & 4 & & & 1 & & & & & & & & & & & & & & & 1 & & & & & & & & & 7 & 100 & 0.35 \\
\hline Pulicaria undulate & & & & & & & & & & & & & & & & & 3 & 1 & & & & & 1 & & & & 1 & 2 & & 8 & 90 & 0.4 \\
\hline Tanacetum sinaicum & & & & & 1 & & & 1 & & & & & & & & & & 3 & & & 1 & & 1 & & & & & & & 7 & 45 & 0.35 \\
\hline \multicolumn{33}{|l|}{ Ephedraceae } \\
\hline Ephedra alata & & & 3 & & & & & & 1 & & & & & & & & 5 & 3 & & & & & & & & & & & & 12 & 100 & 0.6 \\
\hline Ephedra aphylla & & & & & & 1 & & & & & & & 1 & & & & 2 & & & & & & & & 1 & & & & & 5 & 60 & 0.25 \\
\hline \multicolumn{33}{|l|}{ Euphorbiaceae } \\
\hline $\begin{array}{l}\text { Euphorbia sanctae- } \\
\text { catbarinae }\end{array}$ & & & 4 & & & & & 2 & & & & & & & & & 3 & 4 & & & & 1 & & 1 & & & & & & 15 & 85 & 0.75 \\
\hline \multicolumn{33}{|l|}{ Hypericaceae } \\
\hline Hypericum sinaicum & & & & & & & & & & 1 & & & & & & & 1 & 2 & & & & & & & 1 & & & 2 & 1 & 8 & 95 & 0.4 \\
\hline \multicolumn{33}{|l|}{ Lamiaceae } \\
\hline Lavandula coronopifolia & & & 1 & & & & & & & & & & & & & & 3 & & & & & 1 & & & & 1 & & & & 6 & 40 & 0.3 \\
\hline Phlomis aurea & & & & & 1 & & & & & & 2 & & & & & & 2 & 1 & & & & & 1 & & & & & & & 7 & 50 & 0.35 \\
\hline Stachys aegyptiaca & & & & & 3 & & & & & & & & & & & & & 2 & 1 & & & & & & 1 & & & & & 7 & 50 & 0.35 \\
\hline Teucrium leucocladum & & & & & & & & & & & & & & & & & 3 & 3 & & & & & & & & & & & & 6 & 55 & 0.6 \\
\hline Teucrium polium & & & & 2 & & 1 & & & & & & & & & & & & 2 & & 1 & 1 & 1 & & & & & & & & 8 & 50 & 0.4 \\
\hline Thymus decussatus & & & & & & & & & 1 & & & & & & & & & & & & & & & & & & & & & 1 & 100 & 0.05 \\
\hline \multicolumn{33}{|l|}{ Rubiaceae } \\
\hline Galium sinaicum & 1 & & & & & & 1 & & & & & 2 & & 1 & 2 & 1 & & & & & & & & & 3 & & & 1 & & 12 & 100 & 0.6 \\
\hline Total no. & 1 & 1 & 16 & 3 & 7 & 3 & 1 & 3 & 2 & 3 & 2 & 2 & 1 & 1 & 2 & 1 & 26 & 25 & 1 & 4 & 3 & 4 & 5 & 1 & 6 & 1 & 1 & 5 & 1 & 132 & ----- & $-\cdots$ \\
\hline
\end{tabular}

Morphologically identified taxa: Ab: Absidia corymbifora; Ac. sp.: Acremonium sp.; Ac. st: Acremonium strictum; Al: Alternaria alternata; As. fla: Aspergillus flavus; As. nig: A. niger; As. sp.: Aspergillus sp.; As. sy: A. sydowii; B: Bacteria; Ch. glo: Chaetomium globosum; Ch. spr: C. spirale; Co: Cochliobolus lunatus; Em: Emericella versicolor; Eu: Eurotium sp.; Fu. ox: Fusarium oxysporum; Fu. sp.: Fusarium sp.; D.M.S.: Dark Mycelia Sterilia; W.M.S.: White Mycelia Sterilia; Mu: Mucor fuscus; Ni: Nigrospora sphaerica; Pn. ch: Penicillium chrysogenoum; Pn. co: Penicillium corylophilum; Pn. sp.: Penicillium sp.; Ph: Phoma leveillei; Pl: Pleospora tarda; Sc: Scopulariopsis sp.; Ul. at: Ulocladium atrum; Ul. ch: U. chartarum; Y: Yeast; C.R.: olonization Rate; I.R.: Isolation Rate 


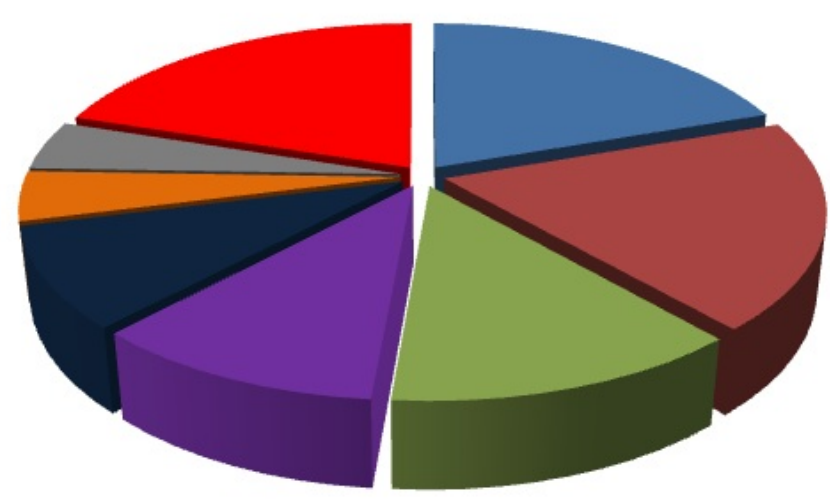

Dark sterile mycelia $19.69 \%$
White sterile mycelia $18.93 \%$
Acromonium sp. $12.87 \%$
- Aspergillus sp. $10.6 \%$
- Penicillium sp. $9.1 \%$
Pleospora tarda $4.5 \%$
Ulocladium sp. $4.5 \%$
- Others $20 \%$

Fig 1 Relative frequencies of different endophytic taxa isolated from 18 Saint Katherine medicinal plants. "Others" include rare and infrequent endophytic fungal species.

25\% for Penicillum). Acremonium strictum was obtained from 6 host plants, with major occurrence in Launea spinosa (relative frequency $57.1 \%)$.

Rare and infrequent endophytic fungal species were Absidia corymbifora, Chaetomium globosum, C. spirale, Cochliobolus lunatus, Emericella versicolor, Eurotium sp., Fusarium spp., Mucor fuscus, Nigrospora sphaerica, Phoma leveillei, and Scopulariopsis sp., all belonging to ascomycetes or anamor-phic fungi, except for the zygomycetes, Absedia corymbifora and Mucor fuscus. Previous studies have found that most endophytic fungi belong to the ascomycetes and anamorphic fungi (Huang et al. 2001).

Alternaria, Chaetomium, Fusarium, and Phoma are common endophytic genus that have been reported in many previous studies, but only one isolate of Phoma leveilleia was detected from host plant Euphorbia sanctae-catharinae, three Alternaria isolates were obtained from Adiantum capillusveneris and Teucrium polium, for Chaetomium globosium, also three isolates were obtained from Adiantum capillus-veneris, and Hypericum sinaicum, and three isolates of Fusarium were obtained from one host, Galium sinaicum.

Endophytic bacteria were obtained from Thymus decussatus and Ephedra alata (relative frequency $100 \%$ and $8.3 \%$, respectively). However, the isolation medium contained an antibiotic to inhibit bacterial growth. Endophytic yeast was obtained from Hypericum sinaicum (relative frequency $12.5 \%$ ). The four isolates of Nigrospora spherica, the six isolates of Pelosora tarda, and six isolates of Ulocladium came from three, four, and three different host plants, respectively. Some endophytes, were restricted to one specific host plant suggesting host specificity. For example, Absedia corymbifora, Cochiobolus lunatus, and Eurotium were found in only Alium sinaicum. Chaetomiun spirali was obtained from Phlomis aurea, Emericella vercicolour from Ephedra aphyla, Mucor fuscus from Stachys aegyptiaca, and Scopulariopsis from Lavandula coronopifolia.

\section{Antibacterial and anticandial activities}

Ethyl acetate crude extract of 132 endophytic isolates from the Saint Katharine medicinal plants were screened for their antibacterial and anticandidal activities, and the most active extracts are listed (Table 2). The remaining extracts showed a narrow spectrum of activity against only one or two pathogenic test organisms, or showed no activity. Fiftyfive isolates (55.5\%) of 99 screened strains, exhibited significant inhibitory activity against a wide range of pathogenic test microorganisms, with diameters of inhibition zones ranging from 9 to $27 \mathrm{~mm}$ for the test bacteria, and from 8 to 31 $\mathrm{mm}$ for test Candida on disc diffusion assay.

It is clear from the results that most of 55 fungal extracts demonstrated broad spectrum activity against the tested bacteria, Candida albicans and C. tropicalis, but few showed antiyeast activity against $C$. prabsiosis or Saccharomyces cerevisiae. Many active isolates exhibited antibacterial activity compared with the isolates exhibiting antiyeast, this may due to the similarities in eukaryotic characteristics between the endophytic fungi and the test organ isms (Hugo 1998). Approximately $49 \%$ of dominant 
Table 2 Antibacterial and Anticandidal activities of 55 endophytic isolates of 99 morphospecies endophytes

\begin{tabular}{|c|c|c|c|c|c|c|c|c|c|c|c|c|}
\hline Host Plant & $\begin{array}{l}\text { Endophytes/ Test } \\
\text { organism }\end{array}$ & $\begin{array}{l}\text { C. } \\
\text { alb }\end{array}$ & C. $t$ & C. $\mathbf{p}$ & Sac. & Staph & Bs. & M. & $\begin{array}{l}\text { E. } \\
\text { coli }\end{array}$ & Ps. & K. & A. $\mathbf{f}$ \\
\hline Stachys aegyptiaca & Mucor fuscus & 23 & 19 & 9 & ---- & 20 & 21 & 23 & 20 & 21 & 20 & 25 \\
\hline Stachys aegyptiaca & Aspergillus flavus & 16 & 30 & ---- & ---- & 20 & 16 & 25 & 20 & 20 & 21 & 27 \\
\hline Galium sinaicum & Pleospora tarda & 15 & 25 & ---- & ---- & 16 & 12 & 20 & 16 & 12 & 12 & 14 \\
\hline Galium sinaicum & Aspergillus sp. & 18 & 19 & ---- & ---- & 23 & 20 & 23 & 24 & 22 & 20 & 24 \\
\hline Galium sinaicum & Fusarium sp. & 12 & 18 & ---- & ---- & 10 & 12 & 14 & 10 & 12 & 12 & 12 \\
\hline Tanacetum sinaicum & white sterile mycelia & 16 & 16 & 14 & ---- & 18 & 18 & 18 & 16 & 18 & 16 & 18 \\
\hline Tanacetum sinaicum & Penicillium sp. & 14 & 21 & ---- & 12 & 11 & 15 & 12 & ---- & ---- & 11 & 9 \\
\hline Launea spinosa & Acremonium strictum & 22 & 22 & 9 & 16 & 19 & 25 & 26 & 26 & 25 & 22 & 22 \\
\hline Launea spinosa & Penicillium chrysogenoum & 16 & 23 & ---- & 9 & 15 & 20 & 20 & 15 & 15 & 19 & 20 \\
\hline Launea spinosa & Aspergillus niger & 15 & 9 & 8 & ---- & 18 & 18 & 22 & 23 & 20 & 20 & 26 \\
\hline Achillea fragrantissima & Dark sterile mycelia & 23 & 21 & 8 & ---- & 20 & 22 & 23 & 21 & 20 & 20 & 19 \\
\hline Achillea fragrantissima & Dark sterile mycelia & 15 & 21 & 9 & ---- & 17 & 24 & 12 & 23 & 20 & 19 & 20 \\
\hline Achillea fragrantissima & white sterile mycelia & 19 & 17 & 8 & ---- & 20 & 21 & 22 & 21 & 20 & 20 & 19 \\
\hline Achillea fragrantissima & white sterile mycelia & 17 & 15 & ---- & ---- & 20 & 25 & 20 & 20 & 22 & 21 & 23 \\
\hline Achillea fragrantissima & Penicillium corylophilum & 16 & 10 & ---- & ---- & 22 & 23 & 25 & 16 & 19 & 20 & 16 \\
\hline Ephedra aphyla & Dark sterile mycelia & 19 & 22 & ---- & ----- & 20 & 20 & 22 & 20 & 21 & 20 & 25 \\
\hline Ephedra alata & white sterile mycelia & 16 & 16 & 12 & 16 & 18 & 19 & 22 & 20 & 20 & 21 & 23 \\
\hline Ephedra alata & white sterile mycelia & 15 & 9 & ---- & ---- & 10 & 16 & 18 & 14 & 16 & 16 & 16 \\
\hline Ephedra alata & Dark sterile mycelia & 16 & 24 & ---- & ----- & 12 & 22 & 24 & 16 & 20 & 20 & 20 \\
\hline Ephedra alata & white sterile mycelia & 15 & 15 & ---- & 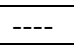 & 14 & 16 & 17 & 13 & 17 & 16 & 19 \\
\hline Euphorbia sancte catherine & Dark sterile mycelia & 16 & 17 & ---- & ---- & 20 & 20 & 21 & 19 & 19 & 20 & 24 \\
\hline Euphorbia sancte catherine & white sterile mycelia & 12 & 12 & ---- & 13 & 15 & 13 & 15 & 15 & 14 & 13 & 17 \\
\hline Euphorbia sancte catherine & Phoma leveillei & 18 & 16 & ---- & ---- & 19 & 19 & 21 & 19 & 19 & 20 & 20 \\
\hline Euphorbia sancte catherine & Dark sterile mycelia & 16 & 20 & ---- & ---- & 17 & 16 & 20 & 15 & 16 & 16 & 20 \\
\hline Euphorbia sancte catherine & Acremonium strictum & 13 & 31 & 11 & 8 & 14 & 11 & 15 & 15 & 12 & 13 & 12 \\
\hline Lavandula coronopifolia & Dark sterile mycelia & 19 & 20 & - & ----- & 20 & 23 & 26 & 20 & 22 & 22 & 26 \\
\hline Chiliadenus montanus & Dark sterile mycelia & 15 & 15 & ---- & ---- & 14 & 13 & 19 & 13 & 14 & 14 & 19 \\
\hline Chiliadenus montanus & Nigrospora sphaerica & 16 & 17 & ---- & ---- & 16 & 20 & 22 & 17 & 20 & 20 & 22 \\
\hline Teucrium leucocladum & white sterile mycelia & 15 & 20 & 10 & ---- & 17 & 16 & 18 & 17 & 17 & 16 & 18 \\
\hline Teucrium leucocladum & white sterile mycelia & 16 & 18 & 15 & 12 & 23 & 18 & 22 & 20 & 18 & 20 & 24 \\
\hline Teucrium leucocladum & Dark sterile mycelia & ---- & 20 & ---- & ----- & 19 & 15 & 16 & 14 & 14 & 14 & 14 \\
\hline Teucrium polium & Alternaria alternata & 18 & 17 & ---- & ---- & 18 & 19 & 17 & 17 & 18 & 18 & 22 \\
\hline Teucrium polium & Nigrospora sphaerica & 15 & 19 & ---- & 9 & 15 & 15 & 20 & 15 & 16 & 15 & 20 \\
\hline Teucrium polium & white sterile mycelia & 12 & 20 & ---- & ---- & 11 & 13 & 16 & 13 & 11 & 12 & 17 \\
\hline Teucrium polium & Penicillium corylophilum & 18 & 31 & ---- & ---- & 18 & 18 & 16 & 24 & 18 & 19 & 24 \\
\hline Teucrium polium & Penicillium chrysogenoum & 16 & 30 & ---- & ---- & 13 & 16 & 20 & 20 & 18 & 18 & 18 \\
\hline Teucrium polium & Aspergillus niger & 19 & 30 & ---- & ---- & 15 & 16 & 20 & 12 & 16 & 17 & 23 \\
\hline Hypericum sinaicum & Ulocladium chartarum & 15 & 22 & 11 & ---- & 13 & 15 & 20 & 13 & 14 & 14 & 20 \\
\hline Hypericum sinaicum & Pleospora tarda & 18 & 21 & ---- & ---- & 20 & 20 & 25 & 21 & 21 & 20 & 26 \\
\hline Hypericum sinaicum & Chaetomium globosum & 22 & 22 & ---- & ---- & 20 & 20 & 23 & 20 & 20 & 20 & 24 \\
\hline Hypericum sinaicum & Yeast & 15 & 30 & ---- & ---- & 19 & 16 & 20 & 13 & 15 & 17 & 20 \\
\hline Hypericum sinaicum & white sterile mycelia & 12 & 19 & ---- & ---- & 9 & 14 & 18 & 16 & 14 & 16 & 20 \\
\hline Artimisia herba alba & white sterile mycelia & 14 & 20 & ----- & ---- & 12 & 15 & 19 & 15 & 15 & 15 & 20 \\
\hline Artimisia herba alba & Dark sterile mycelia & 17 & 13 & $---{ }_{--}$ & ----- & 15 & 18 & 20 & 16 & 16 & 18 & 21 \\
\hline Artimisia herba alba & white sterile mycelia & 20 & 18 & ---- & 15 & 11 & 18 & 17 & 16 & 16 & 18 & 16 \\
\hline Artimisia herba alba & Aspergillus flavus & 21 & 20 & 9 & ---- & 17 & 19 & 21 & ---- & ---- & 19 & 22 \\
\hline Pulicaria undulate & Dark sterile mycelia & 15 & 22 & ---- & 16 & 14 & 20 & 20 & 14 & 20 & 20 & 20 \\
\hline Pulicaria undulate & Ulocladium chartarum & 19 & 22 & ---- & 17 & 17 & 23 & 22 & 14 & 16 & 16 & 23 \\
\hline Pulicaria undulate & Penicillium sp. & 14 & 21 & ---- & 9 & 10 & 18 & 19 & 15 & 14 & 18 & 19 \\
\hline Pulicaria undulate & Dark sterile mycelia & 13 & 20 & ---- & ---- & 15 & 18 & 22 & 14 & 18 & 18 & 22 \\
\hline Phlomis aurea & white sterile mycelia & 14 & 8 & ---- & ----- & 20 & 19 & 20 & 15 & 14 & 16 & 21 \\
\hline Phlomis aurea & Dark sterile mycelia & 8 & 21 & ---- & ---- & 17 & 14 & 17 & 17 & 15 & 15 & 15 \\
\hline Phlomis aurea & Chaetomium spirale & 8 & 21 & ---- & ---- & 12 & 10 & 14 & 13 & 13 & 13 & 14 \\
\hline Phlomis aurea & Penicillium sp. & 15 & 20 & ---- & ---- & 16 & 22 & 21 & 18 & 17 & 20 & 18 \\
\hline Phlomis aurea & Aspergillus flavus & 14 & 30 & ---- & ---- & 16 & 20 & 25 & 19 & 20 & 21 & 25 \\
\hline
\end{tabular}

Code of pathogenic test organism: C. alb: Candida albicans; C. t: Candida tropicalis; C. p: Candida prarapsilosis; Sac.:

Saccharomyces cerevisiae; Staph: Staphylococcus aureus; Bs.: Bacillus subtilis; M.: Microcouss luteus; E. coli:

Escherichia coli; Ps.: Pseudomonas aeuroginosa; K.: Klebsiella pneumonia; A. f: Alcaligenes faecalis. 


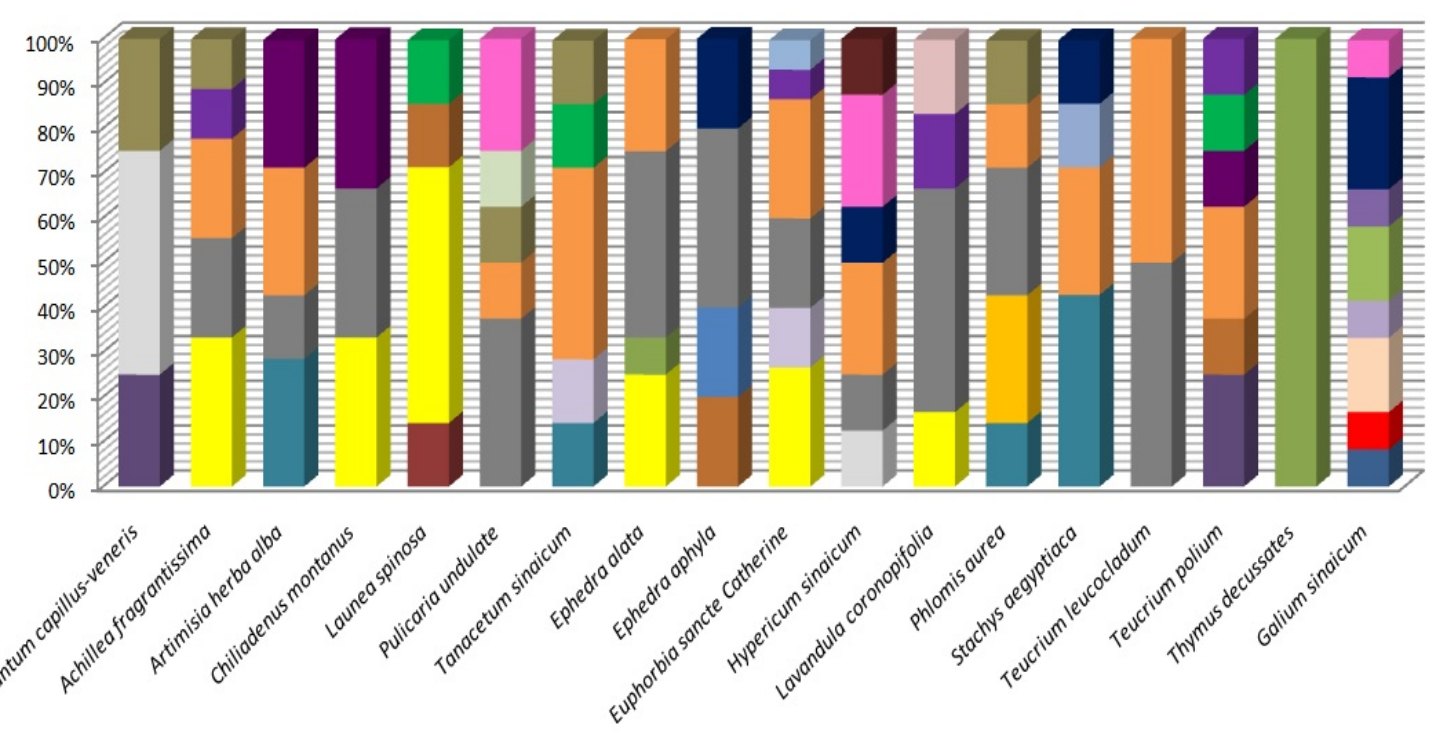

Fig 2 Relative frequances of different endophytic taxa isolated from 18 Saint Katherine medicinal plant

endophytic isolates showing antimicrobial activates were mycelia sterilia Four isolates, Acremonium strictum Ulocladium chartarum and two white sterile mycelia isolated from Launea spinosa, Pulicaria undulata, Ephedra alata, and Teucrium leucocladum, respectively, demonstrated most significant antimicrobial activity on the test organisms. They exihibited broadspectrum antibacterial activity on both gram positive and negative bacteria, and broad anticandidal spectrum against all tested yeast. Three other isolates, Ulocladium chartarum, Aspergillus niger, and Acremonium strictum from Hypericum sinaicum, Launea spinosa, and Euphorbia sanctae-catharinae, respectively, showed moderate activity against all tested organisms. These endophytic isolates are potential candidates for further investigations into bioactive antimicrobial agents.

Isolates of Acremonium strictum from different hosts showed significant difference in biological activity, with a strong antimicrobial effect for those isolates from Launea spinosa, moderate antimicrobial activity when isolated from Euphorbia sancte catherine, and weak activity for other morphospecies from Launea spinosa. Chaetomium globosum isolated from Hypericum sinaicum showed strong antimicrobial activity with a concentration of $250 \mu \mathrm{g}$ per disk and did not show any antioxidant activity (unpublished data), but isolates from Adiantum capillus-veneris did not show this strong antimicrobial activity, showed weak to moderate antimicrobial activity against pathogenic microorganisms at high concentration $500 \mu \mathrm{g}$ per disk, but this isolate showed promising antioxidant activity (unpublished data). The same effect was noticed with isolates of Ulocladium chartarum from $P$. undulata, and from Hypericum sinaicum.

Only 55 isolates of 99 tested showed biological activity. For example, of two isolates of Fusarium from Galium sinaicum only one showed high activity against pathogenic test organisms. This has been noted in previous studies (Li et al. 1996). Many factors changing in the host, e.g., related to season, age, environment, and location, may influence the biology of the endophytes. This observation suggests the importance of the host plant as well as the ecosystem in influencing the general metabolites of endophytic microbes. Production of active metabolites by endophytes may be related to characters of the host plants and to a genetic recombination of the endophyte with the host that might have occurred in evolutionary time. It is possible to imagine that some endophytes developed a genetic system that allowed transferring of information between themselves and host plants (Tan \& Zou 2001, Firáková et al. 2007). Endophytes are a poorly investigated group of microorganisms that represent an abundant source of bioactive agents with potential for exploitation in a wide variety of applications. 
The great biodiversity of endophytes of Saint Katherine medicinal plants, and the presence of many of endophytic isolates exhibiting significant inhibitory activity against pathogenic microorganisms, indicate the ecological importance of studying the relationships between endophytes and their hosts. Furthermore, investigations on other biological activities of endophytes, beside isolation of pure antimicrobial agents, are crucial as an approach to search for novel natural products. On other hand, the use of endophytes as producers of bioactive agents will help in conservation of medicinal plants and maintenance of environmental biodiversity.

\section{Acknowledgments}

The authors express appreciation to the National Research Center, Egypt, in supporting the work reported in this paper. We express also thank Mona Marzouk and Ahmed Hamed in collection and confirming the identification of Saint Katherine medicinal plants, and Wael El-Kateeb for his help in identification of endophytic fungi.

\section{References}

Arnold AE. 2007 - Understanding the diversity of foliar endophytic fungi: progress, challen-ges, and frontiers. Fungal Biology Re-views 21, 51-66.

Arnold AE, Maynard Z, Gilbert GS, Coley PD, Kursat TA. 2000 - Are tropical fungal endophytes hyperdiverse? Ecology Letters 3, 267-274.

Bacon CW, White JF. 2000 - Microbial Endophytes. Marcel Deker, NewYork, USA.

Cohen SD. 2006 - Host selectivity and genetic variation of Discula umbrinella isolates from two oak species: analyses of intergenic spacer region sequences of riboso-mal DNA. Microbial Ecology 52, 463-469.

Danin A. 1978- Plant species diversity and ecological districts of Sinai desert. Vegeta-tion 36, 83-93.

De Almeida MN, Guimaraes VM, Bischoff KM, Falkoski DL, Pereira OL, Goncalves D, De Rezende ST. 2011 Cellulases and hemicellulases from endophytic Acremo-nium species and its application on sugar-cane bagasse hydrolysis. Applied Bioche-mistry and Biotechnology (In Press).

Firáková S, Šturdíková M, Múčková M. 2007 Bioactive secondary metabolites produced by microorganisms associated with plants. Biologia 62/3, 251-257.

Fröhlich J, Hyde KD, Petrini O. 2000 - Endophytic fungi associated with palm. Myco-logical Research 104, 12021212.

Gamboa MA, Bayman P. 2001 -Communities of endophytic fungi in leaves of a tropical timber tree (Guarea guidonia). Biotropica 33, 352-360.

Gonthier P, Gennaro M, Nicolotti G. 2006 Effect of water stress on endophytic mycota of Quercus robur. Fungal Diversity 21, 69-80.

Holliday P. 1998 - A Dictionary of Plant Patho-logy. Cambridge University Press, Cam-bridge, UK.

Huang Y, Wang J, Li G, Zheng Z, Su W. 2001 - Antitumor and antifungal activities in endophytic fungi isolated from pharmaceutical plants Taxus mairei, Cephalataxus fortunei and Torreya grandis. FEMS Immunology and Medical Microbiology 31, 163-167.

Huang WY, Cai YZ, Xing J, Corke H, Sun M. 2007 - Potential antioxidant resource: endophytic fungi isolated from traditional Chinese medicinal plants. Economic Botany 61,14-30.

Huang WY, Cai YZ, Hyde KD, Corke H, Sun M. 2008 - Biodiversity of endophytic fungi associated with 29 traditional Chinese medicinal plants. Fungal Diversity 33, 61-75.

Hugo WB. 1998 - Bacteria. In: Pharmaceutical Microbiology. (WB Hugo, AD Russell, eds.): $4-8 . \quad 6^{\text {th }}$ edition. Blackwell Science, UK.

Jorgensen JH, Turnidge JD. 2007 Susceptibility test methods: dilution and disk diffusion methods. In: Manual of Clinical Micro-biology (PR Murray, EJ Baron, JH Jorgensen, ML Landry, MA Pfaller, eds.): 1152-1172. ASM Press, Washington, USA.

Krings M, Taylor TN, Hass H, Kerp H, Dotzler N, Hermsen EJ. 2007 - Fungal 
endophytes in a 400-million-yr-old land plants: infection pathways, spatial distribution, and host response. New Phytologist 174, 648-657.

Lacap DC, Hyde KD, Liew ECY. 2003 - An evaluation of the fungal "morphotype" concepts based on ribosomal DNA sequence. Fungal Diversity 12, 53-66.

Li JY, Strobel GA, Sidhu R, Hess WM, Ford E. 1996 - Endophytic taxol producing fungi from bald cypress Taxodium distichum. Microbiololgy 142: 22232226.

Mosallam HAM. 2007 - Assessment of target species in Saint Katherine Protectorate, Sinai, Egypt. Journal of Applied Sciences Research 3, 456-459.

Moubasher AH. 1993 - Soil Fungi in Qatar and Other Arab Countries. The Center for Scientific and Research, University of Qatar, Qatar.

Paulus B, Kanowski J, Gadek P, Hyde KD. 2006 - Diversity and distribution of saprobic microfungi in leaf litter of an Australian tropical rainforest, Mycological Research 110, 1441-1454.

Petrini O. 1991- Fungal endophytes of tree leaves. In: Microbila Ecology of Leaves (J Andrews, S Hirano, eds): 179-197. Springer, Berlin, Heidelberg, New York.

Photita W, Lumyoug S, Lumyoug P, Hyde KD. 2001 - Endophytic fungi of wild banana (Musa acuminate) at Doi Suthep Pui National Park, Thailand. Mycological Re-search 105, 15081513.

Promputtha I, Jeewon R, Lumyong S, McKenzie EHC, Hyde KD. 2005a - A phylogenetic evaluation of whether endophytes become saprotrophs at host senescence. Microbial Ecology 53, 579590.

Promputtha I, Jeewon R, Lumyong S, McKenzie EHC, Hyde KD. 2005b Ribosomal DNA fingerprinting in the identification of non sporulating endophytes from Magnolia liliifera (Magnoliaceae). Fungal Diversity 20, 167-186.

Sanders IR. 2004 - Plant and arbuscular mycorrhizal fungal diversity-are we looking at the relevant levels of diversity and are we using the right techniques? New Phytologist 164, 415418.

Schulz B, Boyle C. 2005 - The endophytic continuum. Mycological Research 109, 661-686.

Schulz B, Boyle C, Draeger S, Römmert AK. 2002 - Endophytic fungi: a source of novel biologically active secondary meta-bolites. Mycological Research 106, 996-1004.

Strobel G, Daisy B. 2003 - Bioprospecting for microbial endophytes and their natural products. Microbiology and Molecular Biology Reviews 67, 491-502.

Strobel G, Daisy B, Castillo U, Harper J. 2004 - Natural products from endophytic microorganisms. Journal of Natural Pro-ducts 67, 257-268.

Strobel GA. 2003 - Endophytes as sources of bioactive products. Microbes and Infection 5, 535-544.

Suryanarayanan TS, Kumaresan V. 2000 Endophytic fungi of some halophytes from an estuarine mangrove forest. Mycological Research 104, 1465-1467.

Tan RX, Zou WX. 2001 - Endophytes: a rich source of functional metabolites. Natural Product Reports 18, 448-459.

Wicklow DT, Poling SM. 2009 Antimicrobial activity of pyrrocidines from Acremonium zeae against endophytes and pathogens of maize. Biological Control 99, 109-115.

Wicklow DT, Roth S, Deyrup ST, Gloer JB. 2005 - A protective endophyte of maize: Acremonium zeae antibiotics inhibitory to Aspergillus flavus and Fusarium verticillioides. Mycological Research 73, 274-276.

Zhou D, Hyde KD. 2001 - Host-specificity, host-exclusivity, and host-recurrence in sapro-bic fungi. Mycological Research 105, 1449-1457. 